\title{
ІННОВАЦІЇ В ДЕРЖАВНІЙ ПОЛІТИЦІ ФІНАНСУВАННЯ МЕДИЧНОЇ ДОПОМОГИ В УКРАЇН
}

\author{
ДВНЗ «Тернопільський державний медичний університет імені І.Я. Горбачевського МОЗ України»,
} м. Тернопіль, Україна

\begin{abstract}
Мета: визначення інноваційної складової у державному фрінансовому гарантуванні медичної допомоги для прогнозу стратегічної рентабельності даної інновації.

Матеріали і методи. Використовуючи бібліосемантичний метод та метод системного аналізу, проаналізовано низку законодавчо-нормативних актів України, спрямованих на реформування системи охорони здоров'я.

Результати. Вивчали особливості інноваційного запровадження в реформу системи охорони здоров'я нової моделі фрінансування та державних фрінансових гарантій медичної допомоги населенню. Проаналізовано ризики, які можуть виникнути при запровадженні тих чи інших інновацій в систему фінансування медичної допомоги в Україні.

Висновки. Отримані результати можуть бути використані при подальшій розробці стратегічних планів розвитку системи медичної допомоги.
\end{abstract}

КЛЮчОВІ СЛОВА: державні фрінансові гарантії; надавачі медичних послуг; уповноважений орган; заклади охорони здоров'я.

В основі реформування системи охорони здоров'я (СОЗ) України лежить рефрорма системи фрінансування даної галузі. 27 грудня 2017 р. Президент України підписав закон «Про державні фрінансові гарантії надання медичних послуг та лікарських засобів» (№ 6327) [3]. Отож старт зміни фрінансових взаємовідносин у СОЗ даний. Відповідно до цього передбачаються суттєві відмінності у взаємовідносинах усіх суб'єктів СОЗ в Україні.

Мета дослідження: визначення інноваційної складової у державному фрінансовому гарантуванні медичної допомоги для прогнозу стратегічної рентабельності даної інновації.

Матеріали і методи. Використовуючи бібліосемантичний метод та метод системного аналізу, проаналізовано низку законодавчо-нормативних актів України, спрямованих на ресрормування CO3.

Результати дослідження та їх обговорення. На сьогодні реакцію на запровадження інновацій в охороні здоров'я можна сміливо розцінювати як єдність і боротьбу протилежностей. Зміни, запропоновані Урядом, зачіпатимуть інтереси як лікаря, так і пацієнта та фондотримачів, виводячи їх усіх на початковому етапі із так званої зони комфорту.

В основу реформи лікувальної ланки СОЗ покладено зміну фрінансово-економічної моделі розрахунків. Однак у сьогоднішній ситуації запровадження даних інновацій існують певні ризики, які можуть спровокувати деякі ускладнення запровадження даних змін, що в кінцевому результаті призведе до погіршення здоров'я людей, що $€$ вельми небажаним наслідком.

Першим реальним кроком у напрямку ресормування галузі було ухвалення у квітні 2017 p. Закону України «Про внесення змін до деяких законодавчих актів України щодо удосконалення законодавства з питань діяльності закладів охорони здоров'я» (№ 2002-VIII) [6]. Він передбачає впровадження ряду заходів щодо створення мережі державних та комунальних медичних закладів із достатнім рівнем самостійності для ефективного та своєчасного медичного забезпечення населення. Зокрема, законом задекларовано їх фрінансову та управлінську автономію, а також встановлено спрощений порядок реорганізації закладів охорони здоров'я (3О3) - державних та комунальних установ - у державні підприємства та комунальні некомерційні підприємства. Водночас закон закріплює гарантію того, що кошти, не використані 303 (крім державних та комунальних установ) у поточному році, не вилучатимуться в них і можуть бути використані на фрінансування діяльності закладу (зокрема на оновлення матеріально-технічної бази).

Також закон урегульовує окремі питання, пов'язані з договорами про медичне обслуговування населення, які укладатимуться відповідно до 
спеціального порядку, затвердженого Кабінетом Міністрів України. Однак, якщо, з одного боку, 303 отримали певну свободу, то з іншого - існує низка невизначеностей, які стримують їі реалізацію. Зокрема, відповідно до згаданого Закону, державні та комунальні 303 не підлягають приватизації, водночас за організаційно-правовою формою заклади державної власності можуть утворюватися та функціонувати як казенні підприємства або державні установи, як комунальні некомерційні підприємства або комунальні установи [6]. 3 цього твердження мала б слідувати впевненість у тому, що 303 буде збережено в тому вигляді, як вони існують. Однак тут же допускається можливість їх перепрофрілювання.

Наступне протиріччя. У згаданому законі міститься положення про те, що медична допомога надається безоплатно (за рахунок бюджетних коштів) у 303 та фрізичними особами-підприємцями, які отримали відповідну ліцензію [6]. І тут же уточнюється: лише 3 тими, 3 ким головний розпорядник бюджетних коштів уклав договори про медичне обслуговування населення. Далі наведено й певні фрінансові обмеження: такі договори укладаються лише у межах бюджетних коштів, передбачених на охорону здоров'я на відповідний бюджетний період, на підставі вартості та обсягу послуг із медичного обслуговування, замовником яких $є$ держава або органи місцевого самоврядування. Отож, за умов десіциту таких коштів, обсяги гарантованої медичної допомоги буде обмежено і скорочено - відповідно до «меж» бюджету. 3 виключно економічної точки зору - це раціональний і логічний підхід, однак із позицій медицини - це значний ризик. Адже враховуючи неможливість точно спрогнозувати перебіг хвороби пацієнта, прогнози його одужання тощо, запровадження механізмів нормованого розподілу витрат і нормування медичних втручань приховує небезпеку невизначеності. Навіть жорстке запровадження протоколів лікування і нормативне фінансування на їх підставі, можуть значно обмежити здатність лікаря приймати гнучкі рішення щодо лікування пацієнта, і перетворить його з логічно мислячого фрахівця на суто технічного виконавця. Такий підхід не лише негативно відіб'ється на оздоровчих показниках діяльності лікувальних закладів, а й спричинить ряд конолліктних ситуацій між пацієнтами та медичними працівниками.

Запропоновані зміни передбачають, що фрінансове забезпечення державних та комунальних 303 (бюджетних установ) здійснюється відповідно до бюджетного законодавства. Отож, аби змінити систему оплати праці медичних працівників, а також усю схему фінансових потоків у галузі (через пропоновану Національну службу здоров'я України), доведеться спочатку внести зміни в бюджетне законодавство.
У згаданому законі йдеться й про те, що вартість медичної послуги розраховується з урахуванням структури витрат, необхідних для надання такої послуги відповідно до галузевих стандартів, а методика її розрахунку затверджується Кабінетом Міністрів України [5]. І тут важливо наголосити на необхідності запровадження єдиної методики ціноутворення в системі медичних послуг або ж розробки єдиних тарифів на них не лише на основі структури витрат. Адже витрати на одну і ту ж послугу будуть різними - залежно від вартості використовуваного обладнання, рівня амортизаційних відрахувань, вартості комунальних платежів, які відрізняються у регіонах тощо. Для прикладу наведу тарифри, розраховані в одному із закладів охорони здоров'я м. Кропивницького [7]. Особливу увагу привертає розбіжність вартості гінекологічного огляду акушеркою (21 грн 88 коп.) і звичайного медичного огляду лікаря-хірурга (5 грн 34 коп.) при тому, що сам бланк медичної довідки коштує 4 грн 14 коп. Якщо такий «розмах» у межах одного закладу, можна уявити варіабельність цін на медичні послуги по всій території країни!

Не менше питань виникає і стосовно того, де брати кошти. Адже поряд із заявами про безкоштовне обслуговування населення в 303, їх запевняють у можливості використовувати кошти, отримані від юридичних та фрізичних осіб. В Основах законодавства України про охорону здоров'я у ст. 18 йдеться про те, що «Заклади охорони здоров'я встановлюють плату за послуги з медичного обслуговування, що надаються поза договорами про медичне обслуговування населення, укладеними з головними розпорядниками бюджетних коштів, у порядку, встановленому законом» [4]. Таке твердження потребує дуже великих засторог. Вітчизняна галузь вже стикалася з подібною ситуацією до 1996 р., доки Конституційний Суд України заборонив надавати платні послуги у лікувальних закладах комунальної та державної форм власності. Враховуючи високий рівень невизначеності у вітчизняній медицині, послуг, що надаватимуться поза договорами, ставатиме дедалі більше - кожного разу, як тільки 303 відчує потребу в додатковому фрінансуванні (а це відбуватиметься доволі часто), можна буде розширювати «платний перелік».

Відповідно до законопроекту № 6327 «Про державні фрінансові гарантії надання медичних послуг і лікарських препаратів», ухваленого Верховною Радою України у другому читанні, держава гарантує громадянам повну оплату необхідних їм медичних послуг та лікарських засобів, передбачених програмою медичних гарантій (згідно з тарифом, за рахунок коштів Державного бюджету України) [1]. І тут слід розвіяти ілюзії щодо безоплатності медичної допомоги 
для громадян. Адже такою вона буде виключно в межах програми медичних гарантій. Медичні послуги та лікарські засоби, що не входять до неї, можуть покриватися хіба що за рахунок коштів Держбюджету, передбачених на реалізацію відповідних державних програм та заходів, а також місцевих бюджетів, медичного страхування, юридичних і фрізичних осіб та з інших джерел, не заборонених законодавством. Аналогічно допускається, що органи місцевого самоврядування можуть фрінансувати регіональні програми розвитку та підтримки комунальних 303 (зокрема щодо оновлення їх матеріально-технічної бази, капітального ремонту, реконструкції, підвищення оплати праці медичних працівників), а також місцеві програми надання медичних послуг населенню, громадського здоров'я та інші програми, але лише в межах компетенції органів самоврядування.

Обсяг коштів Державного бюджету України, що спрямовуються на реалізацію програми медичних гарантій, щорічно визначатиметься у законі про Державний бюджет України як частка ВВП, але не менше $5 \%$. Упродовж останніх років на охорону здоров'я в Україні виділялось 3-3,5 \% від ВВП [8]. Тож усі розуміють, що матеріальна база галузі нині доведена до кризового стану і збільшення обсягів її катастрофрічного недофрінансування навіть не в 2 рази не призведе до суттєвого поліпшення ситуації. Наприклад, якщо пацієнт, який звертається в травмпункт із побутовою травмою і потребує невідкладного хірургічного втручання, вимушений витратити понад 5 тис. грн (станом на січень 2018 р.) виключно на медичні засоби та антибіотики, чи може він сподіватися на безкоштовне надання такої допомоги, якщо держава виділятиме на одного пацієнта задекларовані 370 грн (чи 450 грн)? Чи може держава сподіватися на те, що кількість невідкладних звернень настільки поменшає, що вона зможе покрити їх лікування у повному обсязі з цими мізерними коштами? Реалістам же потрібно готуватися до того, що програма гарантованого забезпечення буде дуже обмеженою і пацієнтам доведеться доплачувати за «решту» з власної кишені. А питання чи є у них на це кошти, при найменших зарплатах у Європі, в ракурсі сучасної медичної рефрорми не вивчається.

Вищенаведені застороги повинна буде вирішувати Національна служба здоров'я України, яку МО3 створила як центральний орган виконавчої влади, що забезпечуватиме рівний та якісний медичний захист громадян України в межах гарантованого державою пакета медичної допомоги. Аргументуючи необхідність створення такого органу, МО3 виходить 3 того, що «чим більше страхових внесків об'єднано в один нефрагментований бюджет (тобто в єдиний пул, 3 якого оплачуються страхові випадки), тим ймовірніше, що страховик зможе профрінансувати кожний випадок хвороби, не банкрутуючи» [5]. Очевидно, що страховими внесками МО3 називає частину податків, виділених на систему охорони здоров'я. Та, оскільки, за даними Українського інституту стратегічних досліджень МО3 України, у 2016 р. на 100 тис. населення країни припадало 172 692,9 хвороб говорити про те, що будемо лікувати хворих за рахунок здорових наразі не доводиться [9].

На думку представників МО3, принцип «гроші йдуть за інфрраструктурою», а не «за пацієнтом» не створює стимулів для покращення якості медичної допомоги на рівні закладів, і $€$ причиною неефективності існуючої мережі (більшість закладів недостатньо навантажені, основні фронди зношені, медичне обладнання застаріле) [2]. Однак, принцип «гроші йдуть за пацієнтом» також не стане таким стимулом, адже медична послуга за своєю суттю має негативний (або вимушений) попит (хто ж мріє про відвідування лікаря і отримує задоволення від цього процесу?). Тому згаданий принцип стимулюватиме лише принадження пацієнтів: гарним сервісом, вмовляннями тощо. Медичні заклади всіма силами намагатимуться залучити клієнта, що певною мірою виглядає абсурдно.

У деяких базових аргументах МO3 щодо створення Національної служби здоров'я також приховані певні ризики. Зокрема, коли йдеться про необхідність консолідувати кошти «для закупівлі послуг на такому рівні, який забезпечить замовнику (розпоряднику бюджетних коштів) достатню ринкову силу, щоб домогтися найкращої ціни за послуги та медикаменти» [5]. Насправді ж це є ознакою монополістичного впливу на ринок медичних послуг. Можливо Національна служба здоров'я України й матиме достатню ринкову силу для того, аби змусити виробників (лікарів та фрармацевтів) продавати свої послуги за «найкращими» для служби цінами, але як у цій ситуації почуватимуться самі виробники, скільки вони протримаються на такому ринку і чи вціліє пацієнт між двома вогнями?

Також МO3 обіцяє, що організація закупівлі медичних послуг буде організована таким чином, щоб їх замовник «був зацікавлений діяти в найкращих інтересах пацієнта, а не в найкращих інтересах постачальника (закладів, лікарів)» [5]. Застереження аналогічні до попереднього пункту. Національна служба здоров'я мала б організувати цей процес так, аби сам постачальник був зацікавлений діяти «в найкращих інтересах пацієнта». А для цього йому потрібно платити не за надану послугу, а за профрілактику!

Сумнівним $€$ й намір МОЗ організувати закупівлі медичних послуг у такий спосіб, при якому їх замовник «не мав би фрінансового інтересу відмовляти застрахованим особам у виплаті» [5]. Адже, коли організатор цих закупівель (Національна 
служба здоров'я) виходитиме виключно із тих обсягів коштів, якими володітиме, тож і закуповуватиме послуги саме на чітко визначену суму. А обсяг послуг визначатиме Уряд, знову ж таки, виходячи 3 інтересів бюджету, а не потреб пацієнтів.

Обіцянки забезпечити пацієнтам вільний вибір закладів, а постачальникам - конкуренцію, яка мотивуватиме їх до надання більш якісних послуг та впровадження науково обґрунтованих і економічно ефективних методів роботи впирається в іншу перешкоду. Справа в тому, що вільний вибір пацієнтів обмежений специфікою закладу, рівнем надання допомоги в ньому, територіальною доступністю, а в багатьох випадках і завантаженістю того чи іншого закладу тощо. Якість як мотиваційний критерій також дуже відносне поняття, оскільки вона по-різному оцінюється з точки зору пацієнта, лікаря і держави.

Модель використання бюджетних коштів, яка базуватиметься на принципі стратегічних закупівель через єдиного національного страховика дуже схожа на фрінансування системи охорони здоров'я за принципом системи Семашка. Адже там також був єдиний централізований бюджет, панував плановий розподіл за чітко визначеними показниками (з тією лише різницею, що тоді це були ліжка). Так само виплати для лікування окремої людини не «прив'язувались» до розміру її індивідуальних внесків. Однак тоді це забезпечувало універсальність та рівність доступу до медичної допомоги, лікар не був зацікавлений ні у кількості пацієнтів, ні у їх захворюванні.
MO3 України декларує принцип розмежування фрнкцій замовника і постачальника медичних послуг, коли «єдиний національний замовник не володітиме закладами охорони здоров'я та не керуватиме ними» [5].

Якщо єдиний національний замовник оплачує послуги за фрактом, відповідно до затрат виробника, тоді логічно, що постачальник буде зацікавлений надавати високотехнологічні та високовартісні медичні послуги, бо це збільшуватиме його доходи. Як зробити їх саме такими? Можна проаналізувати досвід Російської Федерації, яка запроваджувала клініко-статистичні групи і оплачувала їх за витратами.

I3 проекту Постанови Кабінету Міністрів України «Про утворення Національної служби здоров'я України» [5] не зрозуміло, чи входитиме у вартість медичної послуги утримання закладу охорони здоров'я. Якщо взяти до уваги рекомендацію, що вартість визначатиметься за структурою витрат - тоді входитиме.

\section{Висновки}

Слід застерегти, що коли СО3 перевести у русло винятково ринкової економіки, вона поводитиметься відповідно до пануючих там ринкових законів і намагатиметься працювати за принципом: «чим більше послуг - тим більше доходів!» Чи ж зможемо тоді назвати наше суспільство гуманним, і чи досягнемо задекларованої мети здоров'я нації?

Перспективи подальших досліджень полягають у подальшому аналізі та вивченні ринку медичних послуг України.

\section{Список літератури}

1. Закон України «Про державні фрінансові гарантії надання медичних послуг та лікарських засобів» (№ 6327) [Електронний документ]. - Режим доступу : http://ukrainepravo.com/law-making/bill_enacted_into_law/zakon-ukrainipro-derzhavni-finansovi-garantii-medichnogo-obslugovuvannya-aselennya/ - Назва з екрана.

2. Концепція реформи фрінансування системи охорони здоров'я України [Електронний документ]. - Режим доступу : http://www.apteka.ua/article/359629 Назва з екрана.

3. Не реформувати медицину неможливо - Президент підписав Закон «Про державні фрінансові гарантії медичного обслуговування населення» [Електронний документ]. - Режим доступу : http://www.president.gov.ua/news/nereformuvati-medicinu-nemozhlivo-rezident-pidpisav-zakon-45286 - Назва з екрана.

4. Основи законодавства України про охорону здоров'я [Електронний документ]. - Режим доступу : http://protokol. com.ua/ua/osnovi_zakonodavstva_ukraini_pro_ohoronu_zdorov_ya_2/ - Назва з екрана.

5. Повідомлення про оприлюднення Проект Постанови Кабінету Міністрів України «Про утворення Національної служби здоров'я України» [Електронний документ]. - Режим доступу : http://old.moz.gov.ua/ua/print/Pro_20161020_0. html - Назва з екрана.

6. Про внесення змін до деяких законодавчих актів України щодо удосконалення законодавства з питань діяльності закладів охорони здоров'я (№ 2002-VIII) [Електронний документ]. - Режим доступу : http://w1.c1.rada.gov.ua/pls/ zweb2/webproc4_1?pf3511=57374w1.c1.rada.gov.ua/ls/zweb2/webproc34?id=\&pf3511=57374\&pf35401=419708

Назва з екрана.

7. У Кропивницькому прописали тарифи на послуги для медогляду [Електронний документ]. - Режим доступу : http://persha.kr.ua/news/life/98068-u-kropyvnytskomu-propysaly-taryfy-na-poslugy-dlya-medoglyadu/ Назва 3 екрана.

8. Частка видатків місцевих бюджетів у ВВП за січень-березень 2016-2017 р. / бюджетний моніторинг: Аналіз виконання бюджету за січень-березень 2017 р. медогляду [Електронний документ]. - Режим доступу : http://www. ibser.org.ua/sites/default/files/kv_i_2017_monitoring_ukr_0.pdf Назва з екрана.

9. Щорічна доповідь про стан здоров'я населення, санітарно-епідемічну ситуацію та результати діяльності системи охорони здоров'я України. 2016 рік / МОЗ України, ДУ «УІСД МОЗ України». - К., 2017. - 516 с. 


\section{References}

1. Zakon Ukrainy "Pro derzhavni finansovi harantiyi nadannya medychnykh posluh ta likars'kykh zasobiv" (№ 6327) [The Law of Ukraine "On State Financial Guarantees for the Provision of Medical Services and Medicines" (No. 6327)]. Retrieved from: http://ukrainepravo.com/law-making/bill_enacted_into_law/zakon-ukraini-pro-derzhavni-finansovi-garantiimedichnogo-obslugovuvannya-naselennya/ [in Ukrainian].

2. Kontseptsiia reformy finansuvannia systemy okhorony zdorovia Ukrainy [Concept of the reform of the financing of the health care system of Ukraine]. - Retrieved from: http://www.apteka.ua/article/359629 [in Ukrainian].

3. Ne reformuvaty medytsynu nemozhlyvo - Prezydent pidpysav Zakon "Pro derzhavni finansovi harantii medychnoho obsluhovuvannia naselennia" [It is impossible to reform medicine. - The President signed the Law "On State Financial Guarantees of Public Health Services"]. - Retrieved from: http://www.president.gov.ua/news/ne-reformuvati-medicinunemozhlivo-prezident-pidpisav-zakon-45286 [in Ukrainian].

4. Osnovy zakonodavstva Ukrainy pro okhoronu zdorovia [Fundamentals of Ukrainian Health Protection Law]. - Retrieved from: http://protokol.com.ua/ua/osnovi_zakonodavstva_ukraini_pro_ohoronu_zdorov_ya_2/ [in Ukrainian].

5. Povidomlennia pro opryliudnennia Proekt postanovy Kabinetu Ministriv Ukrainy "Pro utvorennia Natsionalnoi sluzhby zdorovia Ukrainy" [Notification on Publication Draft Resolution of the Cabinet of Ministers of Ukraine "On the Establishment of the National Health Service of Ukraine"]. - Retrieved from: http://old.moz.gov.ua/ua/print/Pro_20161020_0.html [in Ukrainian].

6. "Pro vnesennia zmin do deiakykh zakonodavchykh aktiv Ukrainy shchodo udoskonalennia zakonodavstva z pytan diialnosti zakladiv okhorony zdorovia" (№ 2002-VIII) ["On Amendments to Certain Legislative Acts of Ukraine on Improving Legislation on the Activities of Health Care Institutions" (No. 2002-VIII)]. - Retrieved from: http://w1.c1.rada.gov.ua/pls/ zweb2/webproc4_1?pf3511=57374w1.c1.rada.gov.ua/pls/zweb2/webproc34?id=\&pf3511=57374\&pf35401=419708 [in Ukrainian].

7. U Kropyvnytskomu propysaly taryfy na posluhy dlia medohliadu [In Kropivnitskyi, the tariffs for medical surveillance services were registered]. -Retrieved from: http://persha.kr.ua/news/life/98068-u-kropyvnytskomu-propysaly-taryfy-naposlugy-dlya-medoglyadu/ [in Ukrainian].

8. Chastka vydatkiv mistsevykh biudzhetiv u VVP Za sichen - berezen 2016-2017 rokiv /biudzhetnyi monitorynh: Analiz vykonannia biudzhetu za sichen - berezen 2017 roku medohliadu [Share of expenditures of local budgets in GDP JanuaryMarch 2016-2017 / budget monitoring: Analysis of budget execution for January-March 2017 in the field of medical examination]. - Retrieved from: http://www.ibser.org.ua/sites/default/files/kv_i_2017_monitoring_ukr_0.pdf [in Ukrainian]. 9. (2017). Shchorichna dopovid pro stan zdorovia naselennia, sanitarno-epidemichnu sytuatsiiu ta rezultaty diialnosti systemy okhorony zdorovia Ukrainy. 2016 rik [Annual report on the state of health of the population, the sanitary and epidemiological situation and the results of the healthcare system of Ukraine.2016]. MOZ Ukrainy, DU "UISD MOZ Ukrainy" [in Ukrainian].

\section{ИННОВАЦИИ В ГОСУДАРСТВЕННОЙ ПОЛИТИКЕ ФИНАНСИРОВАНИЯ МЕДИЦИНСКОЙ ПОМОЩИ В УКРАИНЕ}

О.Н. Литвинова, Ю.Н. Петрашик, Е.Е. Юриив, Н.А. Теренда, Л.В. Лиштаба, Н.Я. Панчишин

ГВУЗ «Тернопольский государственный медицинский университет имени И.Я. Горбачевского МЗ Украины»,

г. Тернополь, Украина

Цель: определение инновационной составляющей в государственном финансовом обеспечении медицинской помощи для прогноза стратегической рентабельности данной инновации.

Материалы и методы. Используя библиосемантичний метод и метод системного анализа, проанализированы ряд законодательно-нормативных актов Украины, направленных на реформирование системы здравоохранения.

Результаты. Изучали особенности инновационного внедрения в рефрорму системы здравоохранения новой модели фринансирования и государственных финансовых гарантий медицинской помощи населению. Проанализированы риски, которые могут возникнуть при внедрении тех или иных инноваций в систему финансирования медицинской помощи в Украине.

Выводы. Полученные результаты могут быть использованы в дальнейшей разработке стратегических планов развития системы медицинской помощи.

КЛЮЧЕВЫЕ СЛОВА: государственные финансовые гарантии; предоставители медицинских услуг; уполномоченный орган; учреждения здравоохранения.

\section{INNOVATES IN THE STATE POLICY OF FINANCING MEDICAL AID IN UKRAINE}

O.N. Lytvynova, Y.M. Petrashyk, K.Y. Yuriiv, N.O. Terenda, L.V. Lishtaba, N.Y. Panchyshyn

I. Horbachevsky Ternopil State Medical University

Purpose: to determine the innovative component in the state financial guarantee of medical care for the forecast of strategic profitability of this innovation. 
Materials and Methods. Using the bibliosemantic method and method of system analysis, a number of legislative and normative acts of Ukraine aimed at reforming the health care system were analyzed.

Results. The peculiarities of innovative introduction of healthcare reform into a new model of financing and state financial guarantees of medical care to the population were studied. The risks that may arise when introducing certain innovations into the system of medical care financing of Ukraine are analyzed. The obtained results can be used for the further development of strategic plans for the development of the medical care system.

Conclusions. The obtained results can be used in further development of strategic plans for the development of the medical care system.

KEY WORDS: state financial guarantees; providers of medical services; providers of health services; reinbursation.

Рукопис надійшов до редакції 14.03.2018 p.

\section{Відомості про авторів:}

Литвинова Ольга Несторівна - кандидат медичних наук, доцент кафедри соціальної медицини, організації та економіки охорони здоров'я з медичною статистикою ДВНЗ «Тернопільський державний медичний університет імені І. Я. Горбачевського МОЗ України»; тел.: +38(0352) 52-72-33.

Петрашик Юрій Миколайович - кандидат фрілологічних наук, доцент кафедри соціальної медицини, організації та економіки охорони здоров'я з медичною статистикою ДВНЗ «Тернопільський державний медичний університет імені І. Я. Горбачевського МОЗ України»; тел.: +38(0352) 52-72-33.

Юріїв Катерина Євгенівна - кандидат медичних наук, старший викладач кафедри патологічної фрізіології ДВНЗ «Тернопільський державний медичний університет імені І. Я. Горбачевського МОЗ України»; тел.: +38(0352) 43-12-62.

Теренда Наталія Олександрівна - кандидат медичних наук, доцент кафедри соціальної медицини, організації та економіки охорони здоров'я з медичною статистикою ДВНЗ «Тернопільський державний медичний університет імені І. Я. Горбачевського МОЗ України»; тел.: +38(0352) 52-72-33.

Ліштаба Людмила Вікторівна - кандидат медичних наук, асистент кафедри соціальної медицини, організації та економіки охорони здоров'я з медичною статистикою ДВНЗ «Тернопільський державний медичний університет імені І. Я. Горбачевського МОЗ України»; тел.: +38(0352) 52-72-33.

Панчишин Наталія Ярославівна - кандидат медичних наук, доцент, доцент кафедри соціальної медицини, організації та економіки охорони здоров'я з медичною статистикою ДВНЗ «Тернопільський державний медичний університет імені І. Я. Горбачевського МОЗ України»; тел.: +38(0352) 52-72-33. 